\title{
JÁSZ-NAGYKUN-SZOLNOK MEGYE VÁNDOR TANYAI TANÍTÓI ÉS VÁNDOR ISKOLÁI
}

\author{
Szerző: \\ Almási Brigitta (Drs) \\ Eszterházy Károly Egyetem
}

Szerző e-mail címe:

brigitta.almasi1989@gmail.com

\author{
Lektorok: \\ Verók Attila (PhD) \\ Eszterházy Károly Egyetem \\ Fizel Natasa (PhD) \\ Szegedi Tudományegyetem
}

...és további két anonim lektor

\begin{abstract}
Absztrakt
A vándor tanyai tanítóknak kiemelt szerepük volt a külterületen élő gyermekek oktatásában. Eötvös József által 1868-ban bevezetett népoktatási törvény kötelezővé tette a népoktatást 6-12 éves korig, ugyanakkor a tanyavilágban gyermekek százai maradtak analfabéták. Klebelsberg Kuno által elrendelt 1921:30 tc. kimondta a vándortanítói intézmény bevezetését, melynek hátterében a tanyán élő tanköteles gyermekek iskoláztatásának problémája állt.
\end{abstract}

Kulcsszavak: tanyai iskolák,vándor tanyai tanítók, Klebelsberg Kuno, népiskoláztatás

Diszciplina: pedagógia

\section{Abstract}

TRAVELING FARM TEACHERS AND TRAVELING SCHOOLS OF JASZ-NAGYKUN-SZOLNOK COUNTY

Traveling farm teachers played a key role in education children living outside. The law on folk education introduced by József Eötvös in 1868 made folk education compulsory betweenn the ages of 6 and 12, but hundred of children remained iliterate in the farms. Ordered by Kuno Klebelsberg 1921: 30. tc. He announced the introduction of a traveling teaching instutation, which was based ont he problem of education children in compulsory education at the farm.

Keywords: farm schools, traveling farm teachers, Kuno Klebelsberg, folk education

Disciplines: pedagogy

Almási Brigitta (2020): Jász-Nagykun-Szolnok megye vándor tanyai tanítói és vándor iskolái. OxIPO - interdiszciplináris tudományos folyóirat, 2020/1, 23-38. doi: 10.35405/OXIPO.2020.1.23 
E tanulmány célkitűzése: Szolnok megye egykori vándor tanyai tanítóinak munkájával és a vándor iskolákkal kapcsolatos adatok összegyüjtése, rendszerbe foglalása.

A Hajdú-Bihar Megyei Levéltár Évkönyvében Elsődleges forrásként kell megemlítenünk a Jász-Nagykun-Szolnok Megyei Levéltár kiadványát, Adatok Szolnok Megye történetéből (1980, 1989). amelyben kiindulópontként olyan települések adatait találhatjuk meg, ahol vándor tanyai iskola múködött.

A témához kapcsolódó szakirodalomként említjük meg Császár Ferenc (1990): A vándor-tanyai tanitók szerepe a szolnok megyei népoktatás megteremtésében című tanulmányát, amelyben nem csak a vándor tanyai tanító szerepét vizsgálta, hanem kitért a tanítók és az iskola kapcsolatrendszerére is.

A kutatás elsődleges forrását képezei Kárpáti Jenő (2009) A messz̨e látó pász̧tor című életrajzi mûve, ahol Polner Tibor Karcag tanyai iskolájának első vándor tanyai tanítójára emlékszik vissza. JászNagykun-Szolnok Vármegyében volt vándor tanyai tanítók narratívái szolgálnak további primer forrásként a kutatás teljessé tételéhez. Ezek közül a narratívák közül Horváth Margit visszaemlékezését emelhetjük ki, aki Rákóczifalva melletti Prajzik-telepi iskolában tanított. Bodó Béla - aki a Kunhegyes határában lévő Csete tanyai iskola tanítója volt - visszaemlékezése feleveníti 1930-as évek beli vándor tanyai tanítók életét.
Tatár Antal (2017) Tanyai iskolák címú írásában tesz említést Hajdúsági Tükör címú helyi kiadványban ezekről az iskolatipusokról és tanítóikról. Vándor iskoláról és tanítójáról számol be Kovács GyulánéBékési István (2019) Történelmi séta az Alcsi-Holt-Tisza mentén címü könyvében, amelyben a szolnoki alcsiszögi zugiskola megalakulásáról írnak.

Külföldön megjelent szakirodalomban a tanyai iskolák témájához szorosan kapcsolódik a Mara Casey Tieken (2014) Why rural schools matter? címmel megjelent könyve, amelyben külterületen élő emberek mindennapjairól ír. Hasonlóan, mint magyar neveléstörténeti vonatkozásbanegy tanyai/külterületi iskola közösségi és tanulási teret tölt be. Alice Duffy Rinehart (1999) Country school memories: An oral bistory of one room schooling címú könyvében 47 visszamlékezés alapján jelenítette meg 1900-1955 közötti időszakban a „oneroom school" (egy tantermes iskola) mindennapjait. A könyvben betekintést nyerhetünk a 20. századi tanyai iskolázás amerikai történetébe, valamint a jellegzetes tanyai oktatásba. Ezen kívül a tanítók tulajdonságait és a tanyai iskola sajátos kultúráját is ismerteti a szerző.

A témához kapcsolódó további angol nyelvű szakirodalmak Gardener, Clark és Bard, Joe, Wieland, Regi (2006) National Rural Education Assiciation: History, Research, Summary, Conclusions and Recommendations címú alkotása, amelyben az amerikai tanyai iskolák konszolidációjáról írnak. David L. Burton (2013) A History of the rural 
schools in Greene County from 1865-1960 címmel megjelent könyvében a külterületi iskolákban a misszionárusok tevékenységének szerepérét mutatja be 1865-1960 közötti időszakban.

A tanulmány foobb részeit képezik a vándor tanyai iskolák és tanítóik szerepének áttekintése, majd ezt követően rövid betekintést nyerhetünk Jász-NagykunSzolnok Vármegye népoktatási helyzetébe. A vármegyei népoktatási helyzetkép áttekintését követi a vándor tanyai iskolák esettanulmányainak bemutatása. A iskolák kiválasztása során nem korlátozódtunk csupán az 1930-as évek vándor tanyai intézményeinek bemutatására. Lényegesnek tartottuk szem előtt tartani az iskolák számának alakulásának változását, mert ezen vándot tanyai intézményekből nőttek ki az adott város vagy település körzetéhez tartozó állandó jelleggel múködő tanyai iskolái.

\section{A tanyai iskola}

\section{fogalmi megközelítése}

A tanyai iskola tanyásodott határrászen felállított külterületi alapfokú oktatási intézmény, amely a zárt településen kívül esik. Az épület elosztását tekintve egy vagy két tanterembôl áll és egy tanítói lakásból (Ortutay, 2006).

A tanyai iskolában a diákok osztatlan vagy csak részben osztott tanítási rend szerint tanulnak, akiket általában tanító házaspárok tanítanak. Az intézmény való eljutást sokszor akadályozzák az időjárási viszonyok, különösen a téli és az őszi csapadékos időszakban.

A tanyai iskola fogalmi megközelítése sokkal több annál, mintsem egyetlen mondatban definiáljuk. Nem csak oktatási, hanem közművelődési feladatokat is ellátó intézmény. A kultúra és a művelődés színtere, ahol bálok, gyűlések, politikai rendezvények, tanfolyamok, tanácsadások, szavazások megrendezésének helyszíne.

Ezen kívül a vallásgyakorlás színhelye is a pusztai népek számára. A tanyai iskola tantermétôl a kápolnát deszkaajtó választja el.

A két világháború között sok tanyai intézmény felállítására került sor, elmondhatjuk, hogy ezek az iskolák a puszta ékességei voltak, hiszen a magyarságot kifejező építészeti stílusban épültek (Ortutay, 2006).

\section{A vándor tanyai iskolák} és a vándor tanyai tanítók szerepének áttekintése

Eötvös József által 1868-ban kiadott népoktatási törvény kimondta a gyermekek tankötelezettségét 6-12 éves korig. A tankötelezettséget szigorúan vették, azok a szülők, akik nem járatták rendesen gyermeküket iskolába, pénzbírsággal büntették. A tanyákon azonban több száz gyermek maradt analfabéta. A trianoni békeszerződés utáni helyzetkép negatív képet festett az oktatás tekintetében. Klebelsberg Kuno, vallás- és közoktatásügyi 
miniszter a felemelkedéshez vezető utat a kultúrában és a mûvelődésben látta (Kozák, 2016).

A XX. század elején a tanyai tanköteles gyermekek oktatásának megoldása egyre inkább sürgetőbb üggyé vált, ezért Klebelsberg Kuno, 1921.30. törvénycikkében bevezette a vándortanító intézményt, amely biztosította az iskoláztatást a pusztán, tanyán és telepen (Vaskó, 1975).

A tanyán, vagy a tanyai körzetben lakó tankötelesek oktatásának biztosítása érdekében, ha nem történik rendelkezés határidőn belül, vagy ha a földbirtokosokkal való tárgyalás útján nem tud kiteljesedni a gyermekek oktatása, ebben az esetben a törvényhatósági közigazgatási bizottság felterjeszti a vallás-és közoktatásügyi miniszterhez a tanyai iskolák létesítésének problémáját, ahol elrendelik a külön népiskola felállítását vagy a vándortanító alkalmazását (Rendelet 1.)

Az 50. §-ban olvasható, hogy az iskoláztatás biztosítása érdekében a rendelet kiterjed a legközelebbi nyilvános elemi népiskolától $3 \mathrm{~km}$-nél távolabb lévő területre, többek között olyan pusztára, telepre, iparterületre, ahol 20 család él és az iskoláztatást megnehezítik a természeti tényezők (Rendelet, 2).

A tankötelesek iskoláztatásnak biztosításáról kötelesek gondoskodni azok a természetes vagy jogi személyek, akik a tanyai körzetben birtokkal rendelkeznek. $\mathrm{Az}$ iskolába járás kötelezettségén túl a vasárnapi istentisztelet is biztosítaniuk kell. A törvény $51 \S$-a. rendelkezik a tankötele- sek iskolába való szállításáról. Fuvarral, vagy pedig más közlekedési eszközzel kell biztosítani a gyermekek iskolába való eljuttatását. A tanyai körzetben vándortanítónak kell ellátni a gyermekek oktatását, s ezen körzetekben külön elemi népiskolát kell felállítani.

Vándortanító alkalmazására vagy tanyai iskola létesítésére több tanyai körzet is egyesülhet, ha az a tanköteles gyermekek számára megközelíthető. Akik hozzájárulnak a vándortanító alkalmazásához vagy pedig a tanyán felállított községi vagy állami elemi népiskola költségeihez, mentesülnek a községi iskolaadó alól (Rendelet 3).

A tanyai iskolás gyermekek számára a vándor tanyai iskolában ki kell alakítani a megfelelő helységet. A vándortanító alkalmazására pedig megfelelő lakást kell biztosítani 1-1 szobával, továbbá gondoskodni kell a tanító fuvarozásáról is és el kell vinni azokba a tanyai iskolákba, ahol tanítania kell (Rendelet, 4).

A tanító munkáját az iskolában 3 tagból álló iskolaszék ellenőrzi (Vaskó, 1975). A tanítót az a személy nevezi ki, aki az iskola fenntartásának költségének $2 / 3$ részét fizeti. A tanítónak rendelkeznie kellett a szükséges szakképesítéssel, kinevezését a közigazgatási bizottság erôsítette meg, majd ezt követően esküt kellett tennie a királyi tanfelügyelőnek (Rendelet 5).

A kötelező népoktatás megvalósítását igyekezett megerősíteni Klebelsberg Kuno 1926:7. törvénycikk a mezőgazdasági népesség érdekeit szolgáló népiskolák 
létesítésérôl és fenntartásáról. A törvényben Klebelsberg érdekeltségi népiskolák felállítását írta elő. „Ennek a célnak megvalósítására népiskola állítása és építése hivatalból mindenütt elrendelhető, ahol egy természeti vagy jogi személynek, vagy többeknek tulajdonában, vagy hitbizományi birtokában levő, legalább másfél, legfeljebb négy kilométer sugarú területen (körzetben) szétszórtan vagy tömörülve az utolsó három év átlagát számítva legalább 20 család vagy 30 mindennapi tanköteles lakik és a körzeten belül valamennyi tanköteles befogadására alkalmas más iskola nincs. A községek (városok) külterületén ekként keletkező érdekeltségi jellegű népiskola, mint közintézet önálló jogi személy; szervezetét a vallás- és közoktatásügyi miniszter rendelettel állapítja meg, fenntartóját a 4. §-ban meghatározott érdekeltség alkotja, mely úgy a létesítés, mint a fenntartás terheit viseli." (1926:7 törvénycikk).

Jász-Nagykun-Szolnok Vármegye Tanügyi Közlönye tételesen felsorolta a vándor tanyai tanítók feladatkörét. Ök voltak azok az értelmiségiek, akik lámpásként mutatták az utat a tanya lakóinak. Munkájuk túlmutatott az oktatási feladatokon, hiszen az élet valamennyi területén jártasnak kellett lenni, mint a mezőgazdaság, egészségügy, állattenyésztés.

A vándor tanyai tanítónak tájékozottnak kellett lennie jogi kérdésekben. Feladatuk közé tartozott a közigazgatás képviselete is, így a tanítóknak jó érzékkel kellett rendelkezniük hivatalos levelek megfogalma- zásához, terjeszteniük kellett a rendeleteket. Ugyancsak a tanítók feladatkörébe tartoztak a csecsemőgondozási és családvédelmi feladatok. A közegészségügyről átfogó ismeretekkel kellett rendelkezniük: ismeretterjesztő előadásokat kellett tartaniuk a védőoltásokról, alkoholfogyasztás ártalmairól, elsősegélynyújtásról és az egészséges táplálkozásról (Császár, 1990).

\section{Jász-Nagykun-Szolnok vármegye népoktatása Klebelsberg Kuno idején}

Jász-Nagykun-Szolnok Vármegye 1876ban három közigazgatási egységből alakult meg, ahol összesen 249 tanító tanított. A tankötelesek száma 41 200, de csak 26 532 tanuló járt iskolába. A puszták területén sok helyen nem volt oktatási intézmény, ha volt is, nem feleltek meg az alapvető higiénés feltételeknek (Zádorné, 1996). Klebelsberg idején a vármegyében az uradalmak nem hajlottak iskolák felállítására. További nehézséget okoztak ezzel az uradalmak határain élő tanköteles gyermekek iskoláztatásában, ezért az állam kénytelen volt tantermet bérelni az uradalomi iskolában és az határon túl lakó gyermekek iskoláztatásának érdekében erre a célra külön tanítót kellett fogadni. 1941-ben Kengyelen az Erzsébet-majori elemi iskolában a rákóczifalvai Prajziktelepi iskola tanulói számára béreltek tantermet (Császár, 1990).

Jász-Nagyun-Szolnok Vármegyében a Klebelsberg Kuno által kiadott 1926:7. tc. 
megjelenését követően az iskolák száma felekezeti megosztottság szerint a következőképp alakultak az 1934-1935-ös tanévben (1. táblázat). Az 1. táblázat adataiból láthatjuk, hogy 122 állami és 26 községi iskola létesült. Felekezeti iskolák tekintetében 80 római katolikus, 38 református 8 izraelita és 2 evangélikus intéz- mény felállítására került sor. Az iskolák közül 11 intézmény magánjelleggel, és egy intézmény társulási iskolaként látta el az oktatási feladatokat. Jász-Nagykun-Szolnok Vármegyében 16 uradalmi iskolát találhatunk 1938-ban, számuk alig növekedett (Császár, 1990).

1. táblázat: Az iskolák száma felekezęti megosztottság szerint 1934-1935-ös tanévben (forrás: Bene, 1935. 277.)

\begin{tabular}{|c|c|c|c|c|}
\hline Fenntartó/felekezet & Iskola & Tanterem & Tanerö & Tanuló \\
\hline állami & 122 & 271 & 360 & 17.312 \\
\hline községi & 26 & 42 & 43 & 2.672 \\
\hline római katolikus & 80 & 277 & 287 & 17.383 \\
\hline református & 38 & 202 & 203 & 11.979 \\
\hline evangélikus & 2 & 3 & 3 & 129 \\
\hline izraelita & 8 & 13 & 13 & 319 \\
\hline magán & 11 & 11 & 11 & 704 \\
\hline társulási & 1 & 1 & 1 & 34 \\
\hline Összesen: & 288 & 820 & 921 & 50.532 \\
\hline
\end{tabular}

Az 1934-35-ös tanévben a korábbi adatokhoz képest 277 iskolával többet, összesen 565 iskolát találhatunk (2. táblázat). Ezzel ellentétben viszont az uradalmi iskolák száma csak 21 volt. Az uradalmak nem voltak érdekeltek abban, hogy földjeiken dolgozó cselédjeik gyermekei számára iskolát létesítsenek és hozzájáruljanak a mûvelődésükhöz. A vándoriskolák megszervezését nehezítette a földbirtokosok együttműködésének hiánya az iskolákkal kapcsolatban. Előfordult, hogy elbocsájtották a többgyermekes cselédjeiket (Vaskó, 1982).
Klebelsberg Kuno iskolaépítési programjának köszönhetően 5000 tantermet és tanítói lakást állítottak fel az Alföld területén (Szabó, 2000).

2. táblázat: Az iskolák megoszlása 1944-ben (forrás: Császár, 1900. 71.)

\begin{tabular}{|l|c|}
\hline \multicolumn{1}{|c|}{ Iskola típusa } & n \\
\hline Állami & 146 \\
\hline Felekezeti & 129 \\
\hline Községi & 269 \\
\hline Uradalmi & 21 \\
\hline Iskolák száma összesen & 565 \\
\hline
\end{tabular}




\section{Esettanulmányok}

a vándor tanyai iskolák müködéséről Jász-Nagykun-Szolnokvármegyében

1938-ban a Jász-Nagykun-Szolnok Megyei tanfelügyelőség megkezdte a vándor tanyai iskolák felállítását a tanyavilágban. Ekkor már 41 vándor-tanyai iskola múködött a megyében. A legnépesebb tanyai körzetek közé tartozott Karcag, Jászkisér, Kunhegyes (Császár, 1990). Az esettanulmányban Jászkisér, Karcag, Kunhegyes és Szolnok tanyai körzeteiben működő intézményeire helyeztük a hangsúlyt. Az esettanulmányok bemutatása során az adott település vagy város népoktatására vonatkozó adatok lényegesek a feltáró munkában.

A tanfelügyelői hivatal rendelkezett a tanítási idő szabályozásáról a tanyai iskolákban. A szabályozás szerint az egyes iskolákban fél évig tanítson a tanító, majd ezt követően le kell vizsgáztatni a tanulókat. A vizsgáztatás után a következő félévben a többi tanyai körzetben kellett tanítani, viszont ez a gyakorlat nem tudott sokáig működni. Ennek oka az volt, hogy a tankötelesek száma egyre jobban nőtt, így egyre nehezebb volt bérelni olyan tanyai épületeket, amelyek megfeleltek tanyai iskolák kialakítására.

A vándor tanyai iskoláknak lehetett köszönni az Alföld területén kialakuló tanyai iskolahálózat kiépülését, amely állandó jelleggel múködött.

A vándor tanyai iskola terminus arra szolgált, hogy meg lehessen különböztetni azt az intézményt, amely iskolaépülettel rendelkezik a tanyavilágban (Császár, 1990).

Az iskolák tanyai elhelyezését szerény körülmények jellemzik. Az tanítást szolgáló iskolaépületek is régiek voltak, felújításra szorultak. Sok helyen még az alapvető iskolai berendezések (padok) sem voltak meg. A tanyai iskolákban számos helyen egy helyiségben dolgozott és lakott a tanító (Kárpáti, 2009). Az iskolákról és a tanerőkről Tesléry Károly és Gyomai György tanfelügyelők számoltak be az 1930-as években.

\section{Jászsági tanyavilág vándoriskolája}

Jászkisér tanyai oktatása. Jászkiséren az oktatás egyes nyomai már a 16. század közepén feltűntek. A feljegyzések alapján Péter mestör volt a falu első tanítója. A reformáció hatására Jászkiséren is fellendült az oktatás. 1803-1945 között 2 tanító katolikus, még 5 tanító református gyermekeket oktatott. A tanyai gyermekek oktatását az egyetlen Pusztakürtön működô iskola látta el, egy állandó tanerővel 1936ig. Ezt követően négy vándoriskolát állítottak fel, amelyek a felszabadulásig múködtek vándor tanyai iskolaként (Szabó és Szabó, 1989a).

Jászkisér külterülete a megye egyik megnépesebb tanyavilágának számított az 1930-as évek végén. Tánczos Alajos jászkiséri római katolikus vándor tanyai tanító látta el a nevelői feladatokat (Bene, 1940). Az 1930-40-es években a jászkiséri Olva- 
sókör vezetője volt (Győri, 2004). A település határában 373 szétszórt tanyát lehetett találni, amelynek lakosai közül Tánczos Alajos vándor tanyai tanító 277 tanköteles gyermeket írt össze. Kijelölte a körzeti központokat és a tanyai lakosság felajánlotta a körzetek számára azokat az épületeket, amelyek tanításra alkalmasak. Az iskolák kialakításában a tanyai emberek együttműködők voltak, lehetőségükhöz mérten hozzájárultak az iskola tárgyi feltételeinek kialakításában is. Ezzel együtt nem csak iskolát alakítottak ki, hanem egyfajta művelődési teret is. Mindezzel hozzájárultak a tanyai lakosok és gyermekei számára a tanuláshoz és művelődéshez való hozzáféréshez. Részlet Tánczos Alajos visszaemlékezéséből: „A lakosság nagy készséggel csatlakozott nem csak az iskola szervezési munkájához, hanem biztosították az iskola szerény berendezési tárgyait is. Az iskola kultúrközponttá kialakításában is jelentős szerepük volt. Nagy tisztelettel és szeretettel vették körül tanítójukat, ami jelentősen hozzájárult helytállásukhoz a minden kulturáltól elzárt tanyavilágban."

A 3. számú táblázatban láthatjuk Jászkisér tanyavilágának iskolával ellátottságának alakulását 1945 után. A Mihályi és a Réti tanyán új iskolaépület épült fel 1948ban. Jászkisér külterületén 5 tanyai iskolát találhatunk a II. világháború után. 1948 utáni időszakban a tanyai iskolát múködését erre szerveződött külön külterületei igazgatóság felügyelte. Az 1960-as években, a tanyai iskolákban 103 tanulót talál- hatunk (Tiszavidék, IV. évf. 36. 1948. 2.). Ebben az időszakban ezek az intézmények fokozatosan elnéptelenedtek és megszűntek. Leghamarabb a Réti-iskola szűnt meg. A legtöbb tanyai intézmény az 1960-as évek közepén, még legkésőbb 1974-ben a Szellőháti iskola zárta be kapuit (Gál, 1998).

3. táblázat: Jászkisér tanyavilágának iskolával ellátottságának alakulása 1945 után (forrás: Szabó és Szabó, 1989a, 353.)

\begin{tabular}{|l|c|c|}
\hline \multicolumn{1}{|c|}{$\begin{array}{c}\text { Tanya } \\
\text { iskola }\end{array}$} & $\begin{array}{c}\text { Tanerő } \\
\text { száma }\end{array}$ & $\begin{array}{c}\text { Az iskola } \\
\text { megszűnése }\end{array}$ \\
\hline Réti -iskola & 1 & 1952 \\
\hline $\begin{array}{l}\text { Halmaji- } \\
\text { iskola }\end{array}$ & 1 & 1964 \\
\hline $\begin{array}{l}\text { Hetényi- } \\
\text { tanyai iskola }\end{array}$ & 1 & 1966 \\
\hline $\begin{array}{l}\text { Pusztakürti } \\
\text { iskola }\end{array}$ & 2 & 1974 \\
\hline $\begin{array}{l}\text { Szellóháti- } \\
\text { iskola }\end{array}$ & 2 & \\
\hline
\end{tabular}

Karcag tanyai oktatása. Karcag kulturális fejlődésére a 17. századtól a református hitre való áttérés jelentős hatással volt. A pusztákon Albirsi nevű oskolamester nevét jegyezték fel 1690-ből, aki a tatárjárás ideje alatt tanítványait templomba menekítette (Szabó és Szabó, 1989a). 
Ez azért is lényeges adat, mert a református egyház Debrecenen keresztül látta el tanítókkal a várost. Karcagon fiúkat és lányokat egyaránt oktatták. A 18. századtól már rendszeres oktatásról beszélünk, ekkor tért vissza a lakosság Rakamazról. A 1879-ben Karcagon 16 népiskola múködött 16 tanerővel, akik 1861 tankötelest oktattak. 1895-ben 2 külvárosi vegyes iskolát felállítására került sor. 1910/11-es tanévben 1935 református tanköteles gyermeket tanítottak 21 tanteremben. A római katolikus felekezethez tartozó tanulók elemi oktatásában az 1920-as években tapasztalhatunk fejlődést. Mindeddig a katolikusokat 3 tantermes iskolában, majd ezt követően 3 emeletes zárdaépület 4 tantermében tanították. Az 1930-as évek közepéig tehát 3 épületben történt oktatás: A legrégebben épült 1 tantermes, ezt követően 1926-ban épült 5 tantermes iskolában és a zárdában (Szabó és Szabó, 1989a).

Az 1930-as években 5575 tanyai lakos élt a karcagi tanyavilágban. Voltak olyan területek is, ahol bokor-tanyák és tanyaközpontok sem működtek (Császár, 1990). Karcag tanyavilágában a Datyi-Sós tanyán múködött Bugyogó Dúlőn vándor tanyai iskola Az iskola tanítója Pollner Tibor volt. A tanya Karcagról 8 km távolságra volt, amelyet földúton lehetett megközelíteni. A tanya tulajdonosa a többnyire a városban tartózkodott, így a tanyát bérbe tudta adni (Kárpáti, 2009. 203).

A bugyogói iskola nem fest negatív képet, ellentétben a legtöbb vándor tanyai iskolával. Az épület cseréptetős volt, amelyben egy kemencével ellátott szoba töltötte be a tanterem szerepét (Kárpáti, 2009). A tanterem tárgyi feltételei is jobbnak bizonyultak, mint az átlagos tanyai iskolákban: öt támlás lóca, kecskelábú asztal. A berendezések közé tartozott a golyós számológép, 3 db falitérkép, amely szemléltető eszközként szolgált. Az iskolai felszerelést gazdagította a 30-40 db ifjúsági olvasókönyv (Császár, 1990).

Ebben a tanyai körzetben 70 tanköteles tanult, akiket a tanító három csoportba osztott. A tanulók felszerelése viszonylag kevés volt: vonalas és kockás füzet, egy ceruza, olvasókönyv és toll. Az iskolai felszerelések belefértek egyetlen táskába. Az olvasókönyvet egy családban több gyermek is tudta használni, ismeretanyaga nem változott (Kárpáti, 2009).

Az 1950-ben 13 külterületi iskola múködött Karcag határában. Az intézmények államosítása nem volt zökkenőmentes a református egyház ellenállása miatt (SZML Szolnok Alispáni ir. 22913/948. sz.).

A 4. táblázat (Kárpáti, 2009 alapján) foglalja össze a karcagi tanyai iskolákat és tanítóikat az 1940-1960 évek közötti időszakban.

\section{Kunhegyes tanyai oktatása}

Kunhegyesen a 18. században - Karcaghoz hasonlóan - kiemelkedő az oktatásban kiemelkedő szerepe volt a református egyháznak. 1721-ben felvett jegyzőkönyv alapján arra lehet következtetni, hogy 
4. táblázat: Karcag tanyai iskolái és tanitói az. 1940-60 között (forrás: Kárpáti, 2009. 207.)

\begin{tabular}{|l|c|}
\hline \multicolumn{1}{|c|}{ Iskola } & Tanerő \\
\hline Apavára & $\begin{array}{c}\text { Vernicz Béla, } \\
\text { Dobra Márta? }\end{array}$ \\
\hline Berekfürdő & - \\
\hline Bócsa & Bod Lajos \\
\hline Botonás & Polner Tibor \\
\hline Bugyogó & $\begin{array}{c}\text { Sípos Béla, } \\
\text { Dede Kálmán }\end{array}$ \\
\hline Cserhát-belső & Szabó László, \\
\hline Cserhát- külsô & - \\
\hline Ecsegzug & - \\
\hline Gergely & Kovács Mihály \\
\hline Hegedűshát & $\begin{array}{c}\text { Juhász István, } \\
\text { Marcona József } \\
\text { Kás felesége }\end{array}$ \\
\hline Karcag-puszta & - \\
\hline Kiskulcsos & - \\
\hline Kunlapos & Gúth János \\
\hline Tilalmas & Tóth Imre \\
\hline Vajas & \\
\hline
\end{tabular}

Kunhegyesen állandó jelleggel tanító látta el az oktatási feladatokat. Szintén Karcaghoz hasonlóan a debreceni Kollégium által kiközvetített tanítók tanítottak (Szabó, Szabó, 1980. 539.).

Kunhegyes körzetében az 1930-as években 2278 tanyai lakos élt, ahol 5 vándortanító látta el a tanítói feladatokat. Ezek közül a tanítók közül Bodó Béla egykori vándortanyai tanító emlékezetében szintén negatív kép rajzolódik ki az iskolát illetően. $8 \mathrm{~km}$-es távolságokról számol be és a vándor tanyai tanítók mostoha munkakörülményeirôl. Mindezt bizonyítja az is, hogy hogy a tanítót csak a 8 km-re lévő lévő faluban tudták elszállásolni (Császár, 1990).

A város körzetében a tanyai iskolai hálózat kiépülése az 1920-as években bontakozott ki Klebelsberg Kuno iskolaépítési programja nyomán (KSH Szolnok megyei igazgatósága. Községi Törzskönyv. Kunhegyes).

Gyomai György beszámolójának egy részlete Kunhegyes határában lévő Csetetanyai vándor tanyai iskoláról: „A tanyai épület előteréből egyik ajtó a tantermül szolgáló egyik lakószobára nyílt, a másik ajtó a gazda szobájába. A tantermi szoba berendezése: tábla, lócák, padok, kecskelábú asztal, a tanító által készített szemléltető eszközök, végül a tanító vaságya."

Hakku Tungoc törökországi tanügyi szakember magyarországi tanulmányútját Gyomai György tanulmányi felügyelő a következőképpen foglalta össze: „Órákig ült az egyszerű tanyában meghúzódó vándortanyai iskola lócáján Hakku Tungoc török tanügyi vendég. A Szapárfalun, Kenderesen és Kunhegyesen végzett alapos vizsgálódás és tapasztalatok alapján megállapította, hogy ezt az iskolatípust alkalmasnak találta török földre való átültetésre." (Császár, 1990. 74.) .

Szolnok környéki iskolák

Hegyes-balmi düloii iskola. Szolnok iskoláztatásáról szóló első megbízható adat a 15. 
századból való (Halmos, 1927). Eötvös József 1868-ban megalkotott törvénye után Szolnokon az 1878/79. tanévben 19 képesített tanító és egy segédtanító oktatta az 1948 tankötelest. A városban a tantermek száma 20 volt. 1893/94. tanévben újabb elemi iskola felállítására került sor, amelyet Shuster Constantin alapított (Szabó és Szabó, 1989b).

1932-ben Szolnokon 16 elemi iskola működött, ahol 90 tanító látta el az oktatási feladatokat. A tankötelesek száma 3704 fő volt. A külterületen élő ismétlő tankötelesek (12-14 éves korú tanulók) más intézményben nem folytattak tanulmányokat. Tanulmányaikat 4 általános és 1 gazdasági irányultságú továbbképző intézetben zárták le (Szabó és Szabó 1989b).

A Hegyes-Halmi dűlőben múködő vándor tanyai iskolában Hortváth Margit tanítónő a következőképpen vázolta fel az iskolai környezetet: „Elhagyott, eldűlt vályogfalú tanyai épületben, a tantermül szolgáló egyetlen lakószobában, 4x4 méretű helységben 28 tanulóval működött az iskola. Az épülethez ragasztott kamrában laktam és lámpafény mellett készülhettem nap-nap után a tanyai tanítókra zúduló iskolai és iskolán kívüli feladatokra Az iskolában meghúzódott néhány, a gazdákhoz otthonra, a valóságban munkára kihelyezett menhelyi árvagyermek is, szinte megpihenni az iskolában az állandó napi munkától (legeltetés, pásztorkodás). Jó szót és emberi magatartást csak a tanítónőtől nyertek.” (Császár, 1990. 73.).
A Hegyes-Halmi dűlőn múködő iskola a többi intézményhez képest a legnegatívabb képet festi. Nem csak az iskola hiányosságaira mutatott rá a tanítónő emlékezete, de a nevelőszülőkhöz kihelyezett árvagyermekek mostoha körülményeirôl is élethű leírást kaphattunk.

Prajzik-telepi iskola. Rákóczifalván a 19. század végén épült meg iskola. A katolikus felekezethez tartozó tankötelesek oktatása a Rákóczi kastélyban történt. A katolikus iskolaszék 1882-ben alakult meg, ahonnan 2 tanítót közvetítettek ki a faluba (Szabó és Szabó, 1989b). Az 1882-ben megalakult iskolaszék által közvetített tanítók: Haim László és Pesti Lajos voltak. A tanulók létszáma 147 fő volt. A kastélyt a 19. század végén, 1892-ben lebontották (Szabó és Szabó, 1989b). A településen a felszabadulás előtt 4 elemi iskola múködött. Az 1910-es évek elején, 1914-ben a kastély köveiből fejezték be a központi iskolát, amely 3 tantermes volt. Az intézményhez egy igazgatói lakás is tartozott.

A református elemi iskola 1914-1916 között épült, ahol 1-4 osztályig oktatták a tanköteleseket. A Mészáros iskola más néven Kis Iskola egy kocsma átalakítása során vált oktatási intézménnyé. Az alsó tagozatos tanulók számára az 1930-as évek közepén épült fel Giza néni iskolája 2 tanteremmel. Az iskola tanulóinak létszáma az 1925/26-os tanévben 783 volt (Bátor és tsai, s.a.).

Horváth Margit tanítónő a HegyesHalmi iskolán kívül a Rákóczifalván mű- 
ködő Prajzik-telepi (Szolnok Megyei Néplap repertóriuma III. 147.) vándor tanyai iskolában is tanított. Az iskoláról nagyon kevés adat áll rendelkezésre. A fellelhető adatok szerint uradalmi iskolaként múködött. 1948-ban azonban a Rákóczifalva Újtelepen és Prajzik-telepen működő intézményeket megszüntették a gazdasági cselédek elköltözése miatt. Ezt követően Rákóczifalva belterületén létesítettek iskolát a tanyai iskolát helyett (Antal, Győri, és Szurmai, 1973). A Prajzik telepi iskolában tanítók névsorát az 5. számú táblázat foglalja össze (Czirmayné, 2012, 149. alapján).

5. táblázat: A Prajzik telepi iskola tanitói (forrás: Czirmayné, 2012, 149.)

\begin{tabular}{|l|r|}
\hline \multicolumn{1}{|c|}{ Tanító } & \multicolumn{1}{c|}{ Időszak } \\
\hline Horváth Margit Gizella & 1940-es évek eleje \\
\hline Mohácsy Albert & 1940-es évek eleje \\
\hline Szabó Tivadar & $1945 / 1946$ \\
\hline Misák Piroska & $1946-1948$ \\
\hline Terenyi Gizella Katalin & $1948-1950$ \\
\hline
\end{tabular}

Szandapusztai iskola. Szolnok környékén a külterületek benépesítése viszonylag későn kezdődött meg, csak az 1880-as évektől kezdődően. A tanyasodás nem volt számottevő, leginkább az Ugar és Alcsi határrészeken épültek tanyák. Jelentősebb külterületi lakosság Szandán a Szőlőkben élt (Gulyás, 2010). Szandapuszta az 1920as évek végén még nem volt közigazgatási szempontból önálló település. A 33. 307./1927-es Belügyminiszteri rendelet kimondta, hogy a községek és városok kötelessége a külterületi települések közigazgatási viszonyainak rendezése (Cseh, 1989).

Szandapuszta iskolai oktatása a szolnoki bérlők letelepeséhez köthetők. 1879-ben a szandai uradalom tulajdonosát felszólította Szolnok képviselőtestülete, kötelezte uradalmi iskola felállítására (SZML. Szolnok Képviselőtestületi jkv. 1879/106.).

$\mathrm{Az}$ iskola felépítésére nem került sor, így Jász-Nagykun-Szolnok Vármegye Törvényhatósági Bizottsága kötelezte Szolnok várost az intézmény létrehozására a pusztában, amely 1891-ben épült meg, melynek felépítésére 4000 Ft-t vállalati összegért bízták meg Szvitek Károlyt és fiát Szvitek Istvánt. Az iskola felépítéséről szóló határozat az alábbi idézetben olvasható: „A vármegyei tekintetes közigazgatási bizottságnak határozatát a képviselőtestület köztisztelettel tudomásul veszi s tekintettel arra, hogy a város Közönsége népiskolai czélokra, közvény által e czélra fordítani rendelt $5 \%$ - os hozzájárulásnak több mint a kétszeres összegét fordítja, s tekintettel arra, hogy a város Közönsége a folyó évben is hat új segédtanítói állást rendszeresített, s ezen felül a puszta szandai dűlőben új iskolát emeltetett, nem különben a ferenczvárosi iskolát is 2 új tanteremmel s megfelelő számú tanítói lakásokkal is kibővítette, s tekintve végül, hogy a város Közönségének eme nagyfokú áldozatkészségével szemben a miniszterúr ő nagyméltósága az 1894/95. tanév 
végéig, tanévenként megállapított államsegély összege csekélynek mutatkozik, mindezeknél fogva határozza a képviselötestület, hogy vármegyénk tekintetes Közigazgatási bizottsága útján a vallás és közoktatásügyi királyi miniszterúr ő nagyméltósághoz felterjesztést intéz az iránt, hogy népnevelés ügyünket magas figyelmére méltóztatván állami segítségben részesíteni kegyeskedjék." (SZML. Szolnok Képviselőtestületi jkv.1892/101.).

Az egytantermes iskola tanítója Gömbkötő N. János volt. Az intézmény 1914ben 2 tantermesre bővítették, majd 2 tanítót alkalmaztak. A település külterületéhez tartozó Tenyőszigeten az oktatás kezdetben Tóth József földbirtokos házában történt, ezt követően az 1920-as évek végén 1 tantermes 1 tanerôs iskolát állítottak fel (Törökszentmiklós és Vidéke 1927 május 18.).

A szandapusztai központi elemi iskola 1943-ban újabb épületbővítésen esett át. A II. világháborús események során az intézmény és berendezései megrongálódtak.

\section{Megvitatás}

Tanulmányunk megírása során a vándortanyai iskolák és tanítóik adatainak feltárásakor és az intézmények felkutatásánál a történeti háttér összegzése mellett számszerűsíthető adatok elemzésével pontosabb képet kaphattunk. Emellett kutatásunk másik fó kiindulópontja a vándor tanyai tanítók visszaemlékezéseinek elem- zése, narratíváikból történő következtetések levonása volt.

A vizsgált vándor tanyai iskolákban közös motívum, hogy Klebelsberg Kuno iskolaépítési programja során épültek fel. A kutatás során feltérképeztük valamennyi iskola tanerejének és körzethez tartozó intézmények számát. Tanyai iskolásnak és tanítónak nem volt könnyú lenni. A tanítást sok esetben akadályozta az iskolák hiányos felszereltsége, s ahol nem kapott a tanító az iskolával együtt lakást, az intézmény megközelítése. Hasonló akadályozó tényezőkkel kellett szembenézniük a tanyai tanköteles gyermekeknek is, akik ki voltak téve az időjárás viszontagságainak. A tanulóknak az iskolából hazaérve a ház körüli, valamint a mezőgazdasági teendőkbe is be kellett segíteniük, amelyek szintén akadályozták a hatékony tanulást.

A kapott eredmények tükrében elmondhatjuk, hogy Jászkisér tanyai körzetében öt vándoriskola létesült 1952-1974 között, ahol a tanerôk száma ugyanezen időszakban hét fö volt. Karcag külterületén 15 iskola volt, a hiányos források tükrében a tanerôk számát sem tudtuk mindig pontosan meghatározni.

A rendelkezésre álló primer források alapján kilenc tanítóról tudunk, akik a tanyai iskolák megszilárdításában szerepet játszottak. Kunhegyes tanyai körzetében öt vándor tanyai tanító látta el feladatait, azonban itt a körzetek pontos adatai hiányoznak. Egyedül a Csete -tanyai iskoláról találhattunk releváns forrást. Szolnok környékén három vándor tanyai iskoláról 
tudunk. Ezek közül az intézmények közül a Hegyeshalmi - dűlői iskolában egy tanerővel történt az oktatás. A Prajzik-telepi iskolában az 1940-1950-es években pedig öt tanerő tanította a gyermekeket. A Szandapusztai vándor tanyai intézményeiben szintén egy-egy tanerő látta el a feladatokat.

A számokból láthatjuk, hogy a külterületeken az iskolával és a tanerőkkel történő ellátottság igen csekély volt.

Megjegyzés: az OxIPO-model (Mező és Mező, 2019) aspektusából a tanyai iskolák, illetve a vándortanítók esete a tanulásszervezés problémaköréhez tartoznak.

\section{Korlátozások}

A vándor tanyai intézmények felkutatása során sok esetben hiányos levéltári forrásokból kellett dolgoznunk. A kutatás további korlátai közé tartozott a narratív források szubjektivitása és ezen forrásokból származó tanítók neveinek a pontatlan leírása, a legtöbb esetben tehát nehéz volt az objektivitásra törekedni. Tanulmányunkban a kutatást korlátozták a JászNagykun-Szolnok Megyei Levétár forrásainak fizikai állapota, amelyek a legtöbb esetben megrongálódott állapotban voltak, így a kutatáshoz szükséges adatok kinyerése meglehetősen nehéz volt.

\section{Konklúziók}

Jelen tanulmány Jász-Nagykun-Szolnok megye vándor tanyai intézményeinek kezdeti múködését mutatta be röviden. A kutatásban szereplő intézményeket és a fel- lelhető tanítóikat azért lényeges rekonstruálni és újabb kontextusban bemutatni, mert munkásságuk során tették le azt az alapot, amely később az Alföld tanyai iskoláztatásához elengedhetetlen volt.

Az Alföld területén Klebelsberg Kuno iskolaépítési programja során és 1926-ban kiadott népoktatási törvénye életbe lépése után egyre több tanyai iskola felállítására került sor.

A kutatás koránt sem zárható le, hiszen Jász-Nagykun-Szolnok Megye városainak és falvainak külterületén a tanyai iskolák végleges felszámolásáig számos kisiskola alakult meg a maguk sajátos történetével. Így további kutatást eredményeznek a megye tanyai körzetének intézménytörténeti feltárasai.

A tanulmány továbbfejlesztési lehetősége nemzetközi kontextusban is megvizsgálni a tanyai iskolák és tanyai tanítók életútjait, valamint szerepköreit. Nemzetközi szinten kiemelhetjük az Írországban, valamint német területeken kialakult tanyai iskolákat.

Tágabb értelmezési keretben azért is érdemes komparatív elemzést végezni, mert az egyes országok elemi isko-láztatásának történetének megismerése és elemzése is adalékul szolgál jelen kutatás kibővítéséhez.

\section{Köszönetnyilvánítás}

A tanulmány megírása során köszönetet szeretnék mondani a Verseghy Ferenc Könyvtár és Felnőttolvasó Szolgálat munkatársainak az egyes helyismereti gyüjte- 
mények felkutatása során, amely a kutatás előmozdításában sokat jelentett. Ugyancsak köszönettel tartozom a Magyar Nemzeti Levéltár Szolnokon kihelyezett Jász-Nagykun-Szolnok Megyei Levéltár munkatársainak is, kiknek segítségükkel olyan források birtokába jutottam, amelylyel kutatásunkat fel tudtok építeni. A kibocsájtott levéltári forrásokon túl szintén köszönetnyilvánítással tartozom az intézmény történész munkatársainak, akik tanácsaikkal támogatták a tanulmány megírását.

\section{Irodalom}

Antal Árpád- Győri Tibor- Szurmay Ernő (1973.): 25 éve miénk az iskola Dokumentumok az iskolák államositásának Szolnok megyei történetéböl. Szolnok. 87. 91. 92.

Bátor Magdolna, Nagy Erzsébet, Zakar Katalin és Páldi Erzsébet (s.a.): Rákóczifalva földrajzi nevei. 43.

Bene Lajos (1935): Jász-Nagykun-Szolnok Megye népoktatása. In: Scheftsik György (szerk.): Jász-Nagykun-S zolnok várme-gye múltja és jelene. Kalotai László, Szolnok. Letöltés: 2019.12.12. Web:http://vfek. vfmk.hu/00000113/index.html

Császár Ferenc (1990): A vándor-tanyai tanitók szerepe a szolnok megyei népoktatás megteremtésében. In: Múzeumi Levelek. 7072. 74-75.

Cseh János (1989): Szandaszőlős. In: Berecky Ibolya, Selmeczy László és Szurmay Ernő (szerk.): Adatok Szolnok
Megye történetéhez. Szolnok Megyei Levéltár, Szolnok. 183. 188.

Czirmayné Kocsis Róza (2012): Rákóczifalva története I. Rákóczifalva. 149. 153.

Halmos Andor (1927.): A közmüvelödés. In.: Vidor Győző (szerk.): Szolnok. Fejezetek a város múltjából. Szolnok. 31-32.

Kárpáti Jenő (2009) A messzue látó pásztor Karcag. 202.

Kovács Gyuláné és Békési István (2019): Történelmi séta az Alcsi-Holt-Tisza mentén. Szolnok. 26-29.

Mező Ferenc és Mező Katalin (2019): Az OxIPO-modell - az interdiszciplináris kutatások egy lehetséges értelmezési kerete. OxIPO - interdiszciplináris tudományos folyóirat, 2019/1, 9-21. doi: 10.35405/OXIPO.2019.1.9

Ortutay Gyula (szerk.)(2006): Magyar Néprajzi Lexikon. letöltés: 2019.11.12. Web: https://regi.tankonyvtar.hu/hu/ tartalom/tkt/magyar-neprajzilexikon/adatok.html

Pukánszky Béla és Németh András (1996): Neveléstörténet. Nemzeti Tankönyvkiadó Rt, Budapest.

Szabó Attila (2000.): A falusi népiskolák kiépítése. In: Új Pedagógiai Szemle. 2000, 78.

Szabó István és Szabó László (1989): Rákóczifalva. In: Berecky Ibolya, Selmeczy László és Szurmay Ernő (szerk.): $A d a$ tok Szolnok Megye történetéhez. Szolnok Megyei Levéltár, Szolnok 141.

Szabó István ésSzabó László (1989): Szolnok. In: Berecky Ibolya, Selmeczy László és Szurmay Ernő (szerk.): $A d a-$ 
tok Szolnok Megye történetéhez. Szolnok Megyei Levéltár, Szolnok. 280.281.

Szolnok Megyei Néplap repertóriuma III. 147.

Tatár Antal (2017): Tanyai iskolák Hajdúsági tükör, 2017, 10. évf./1. szám, 1416. o.

Vaskó László: $A$ debreceni tankerület vándoriskoläinak történetéhez. (1945-1948) 71. 82. Letöltve: 2019.10.22. Web: http://hbml.archivportal.hu/data/file s/144545222.pdf

Zádorné Zsoldos Mária (1996): Iskolaügy Jász-Nagykun-Szolnok Vármegyében (1876-1900) Jászkunság, 1996, XLII. évfolyam, 3-4. szám, 128-136. o.

Levéltári források:

SZML. Szolnok Képviselótestületi jkv. 1879/106.
SZML. Szolnok Képviselötestületi jkv.1892/101.

SZML Szolnok MTVB OKT. O. ir.1071-69/150.

SZML Szolnok. Alispáni ir. 22913/948. s\%:

Törvények, rendeletek:

130.700./1922. - VIII. sqámú rendelet $61 \S$ 1-2. pont

130.700./1922. - VIII. számú rendelet 50.\$ 1-2 pont 130.700./1922. - VIII. számú rendelet 51.§ 1-2-3. pont 130.700./1922. - VIII. számú rendelet 55.\$ 1-2-3-4. pont 130.700./1922. - VIII. számú rendelet 58.\$ Az 1926. évi VII. törvénycikek a mezógazdasági népesség érdekeit szolgáló népiskolák létesitéséról és fenntartásáról. 1.\$ 